
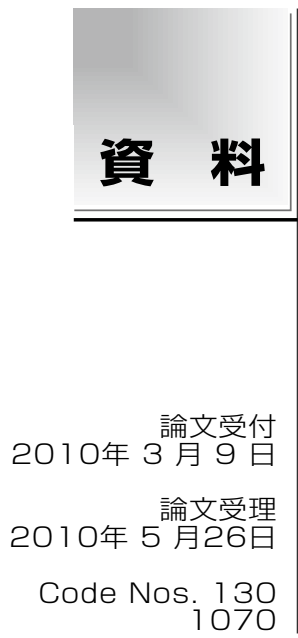

\section{全国の診療放射線技師養成機関における 医療情報教育に関する調查研究}

\author{
大場久照 ${ }^{1)}$ ・ 小笠原克彦 ${ }^{2)} \cdot$ 星野修平 ${ }^{3)} \cdot$ 細羽 実 ${ }^{4}$ \\ 奥田保男 ${ }^{5)}$ ・ 小西康彦 ${ }^{6)} \cdot$ 池田龍二 7 ) \\ 1 ) 北海道情報大学経営情報学部 \\ 2) 北海道大学大学院保健科学研究院 \\ 3)群馬県立県民健康科学大学 \\ 4) 京都医療科学大学 \\ 5) 岡崎市民病院 \\ 6) りんくう総合医療センター \\ 7) 佐賀大学医学部附属病院
}

\section{緒 言}

2007 年 3 月に厚生労働省は, 「医療・健康・介護・ 福祉分野の情報化グランドデザイン」を策定し，医療・ 健康・介護・福祉の各分野にわたる総合的な情報化施 策の推進を掲げた1)。さらに，2009年 7 月には政府の IT 戦略本部より「i-Japan 戦略 2015」が公表され，「医療・ 健康分野」,「教育・人財分野」および「電子政府・電子 自治体」が情報化施策の三大重点分野とされた2). 他
方, 大学の学士課程教育においても, 2008 年 3 月に 中央教育審議会大学分科会制度・教育部会より公表さ れた「学士課程教育の構築に向けて(審議のまとめ)」 のなかで, 学士力の一つに情報リテラシーが提示さ れた ${ }^{3)}$.このような国の医療分野や教育分野の情報化 施策に伴い, 医療機関や学部教育での医療情報教育 の重要度が高まっている.

診療放射線技師養成機関における医療情報教育は,

\title{
A Survey of Medical Information Education in Radiological Technology Schools Hisateru Ohba, ${ }^{1)}$ Katsuhiko Ogasawara, ${ }^{2)}$ Shuhei Hoshino, ${ }^{3)}$ Minoru Hosoba,4) Yasuo Okuda, ${ }^{5)}$ Yasuhiko Konishi, ${ }^{6)}$ and Ryuji Ikeda7)
}

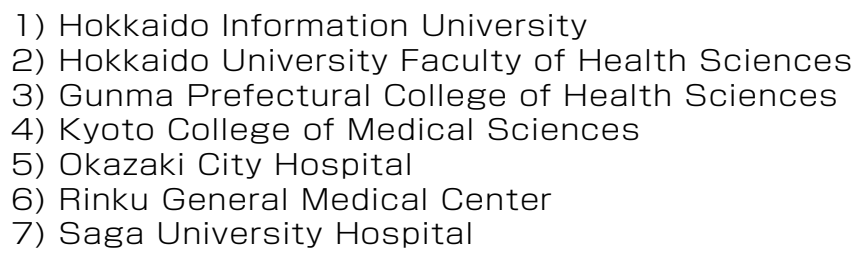

\section{Summary}

The purpose of this study was to clarify actual conditions and problems in medical information education and to propose the educational concept to be adopted in medical information. A questionnaire survey was carried out by the anonymous method in June 2008. The survey was intended for 40 radiological technology schools. The questionnaire items were as follows: (1) educational environment in medical information education, (2) content of a lecture in medical information, (3) problems in medical information education. The response rate was $55.0 \%$ (22 schools). Half of the responding schools had a laboratory on medical information. Seventeen schools had a medical information education facility, and out of them, approximately $50 \%$ had an educational medical information system. The main problems of the medical information education were as follows: (a) motivation of the students is low, (b) the educational coverage and level for medical information are uncertain, (c) there are not an appropriate textbook and educational guidance. In conclusion, these findings suggest that it is necessary to have a vision of medical information education in the education of radiological technologists.

Key Words: medical information education, radiological technology school

別刷資料請求先：干 069-8585 北海道江別市西野幌 59-2 
2001 年の診療放射線技師養成所指定規則の一部改 正および 2003 年の新指導要領の策定によりカリキュ ラムの大綱化が行われ ${ }^{4 \sim 7)}$, 専門分野の教育項目として 新設された「医用画像情報学」のなかで対応すること となった。診療放射線技師国家試験の出題基準では,

「医用画像情報学」の出題項目の一つに「医療情報」が 設定され ${ }^{8)}$, 年々出題数が増加傾向にある.

わが国での診療放射線技師養成機関における医療 情報教育に関する研究は，一大学の学部生を対象と した調査報告はあるが9 12)，全国の診療放射線技師 養成機関を対象とした調査報告はまだないのが現状 である。

そこで，本調査研究では，診療放射線技師養成機関 における医療情報教育の現状と問題点を明らかにし， 医療情報分野に関わる教育指針を提案するために， 全国の診療放射線技師養成機関に対して医療情報教 育に関するアンケート調査を実施し，その調査結果を まとめたので報告する.

\section{1. 調査方法}

\section{1-1 調査対象と調査時期}

調査対象は全国の診療放射線技師養成機関 40 校 （2008 年 6 月 1 日現在，大学 24 校，短期大学 1 校, 専門学校 15 校)とした。調査は郵送による無記名式の アンケート調査とし，アンケートの送付は各診療放射 線技師養成機関の学科主任(教務主任)宛とした。調 査時期は 2008 年 6 月 2 日から約 1 カ月間とした.

\section{1-2 調査項目と評価}

本調査研究では，医療情報教育の教育環境，講義 内容および教育上の問題点に着目し，以下に示す 10 項目を調査項目とした。評価は設問別に単純集計を 行い，診療放射線技師養成機関の医療情報教育の現 状を評価した。

問 1 教育形態(大学, 短期大学, 専門学校)について 問 2 医療情報に関わる教育・研究を行う講座または 研究室の設置について

注 1)医療情報に関わる教育研究については, 医療情報学の教育研究を主とするだけでなく, 画像工学など別分野の教育研究を主として医療 情報学の教育研究を行っている場合も含む. 注 2)医療情報学とは，診療・医学研究・医学 教育・医療行政等，医学のすべての分野で扱 われるデータ・情報・知識をその医学領域の 目的に最も効果的に利用する方法を研究する 科学をいう13).

注 3) 講座とは，教育研究に必要な専攻分野 を設置し，教員(教授，准教授等)を配置して
いることをいう。

問 3 医療情報教育を担当する教員(専任または兼 任)の配置について

注 4) 専任教員とは, 医療情報学を専門として 研究および診療放射線技師養成のための教 育をおもに行う学内教員をいう。

注 5）兼任教員とは，医療情報学以外の分野 を専門として研究および診療放射線技師養成 のための教育をおもに行う学内教員をいう.

問 4 医療情報教育のための設備について

問 5 医療情報教育に使用している教科書について

問 6 教育内容で特に重点を置いて講義している内 容について

問 7 医療情報技師等の情報関連の資格に対する 学生への受検の勧めについて

問 8 医療情報教育の現状の問題点について

問 9 今後の医療情報教育に必要なものについて

問 10 自由記載

\section{2. 結 果}

本調査の回答率は $55.0 \%$ (40 校中 22 校)であった. Fig. 1 に回答校の教育形態の内訳を示す。大学が 15 校と全体の約 7 割であった。

\section{2-1 医療情報教育の教育環境について}

問 2「医療情報に関わる教育・研究を行う講座また は研究室の設置について」は，講座または研究室が “ある”と回答した養成校は 11 校(すべて大学) と全体 の 5 割であり，大学の約 7 割に講座または研究室が 設置されていた(Fig. 2).

問 3 「医療情報教育を担当する教員について」は, 専任教員(医療情報学を専門に研究・教育を行う学内 教員)を配置している養成校は全体の 4 割弱(8 校)で あり, 残りの 14 校は兼任教員(医療情報学以外の分 野を専門として研究・教育を行う学内教員)であった (Fig. 3).また，外部に非常勤講師として委託してい る養成校も5校あった。専任または兼任と回答した 施設当たりの医療情報教育を担当する教員数は，1 人または 2 人という養成校が 16 校あり，全体の約 7 割を占めた。

問 4「医療情報教育のための設備について」は，設 備が“ある”と回答した養成校は 17 校と全体の 8 割 弱を占め，そのうち教育用 PACS (picture archiving and communication system) など教育用医療情報システムを 導入している養成校は約半数の 9 校であった(Fig. 4).

\section{2-2 医療情報教育に関わる講義等について}

問 5 「使用している教科書について」は，「医用画像 


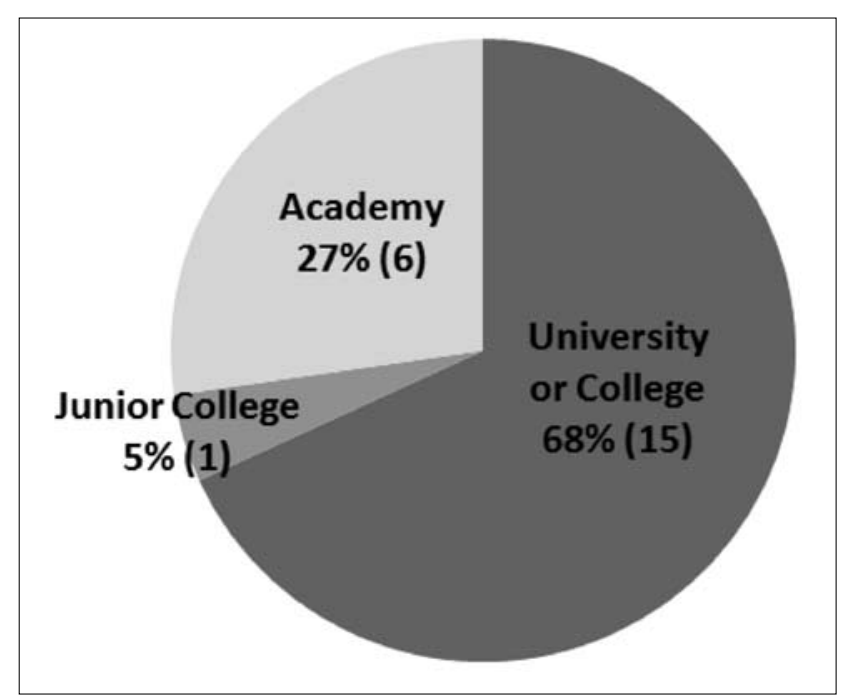

Fig. 1 Response ratio and number of replies according to form of education.

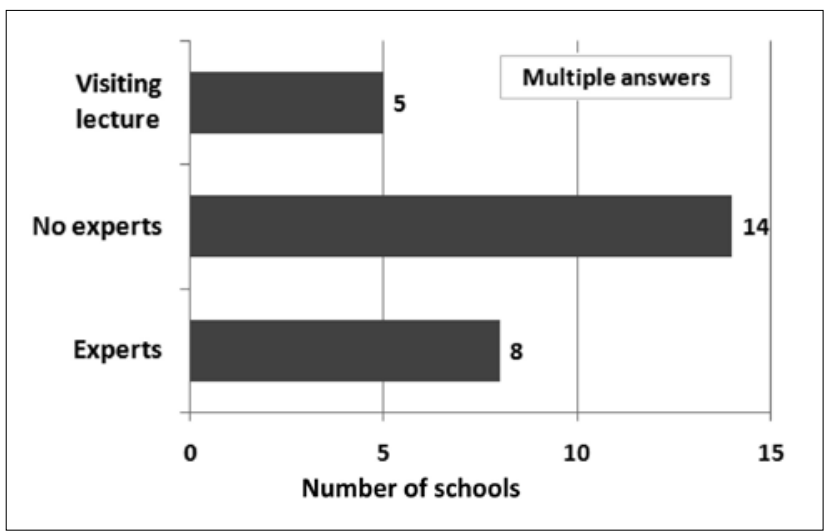

Fig. 3 Number of schools with experts on medical information.

情報学」(桂川茂彦編, 南山堂)が 10 校と最も多く, 次いで「第 2 版 医療情報 医療情報システム編」(日 本医療情報学会医療情報技師育成部会編, 篠原出版 新社) と「第 2 版 医療情報 情報処理技術編」(日本 医療情報学会医療情報技師育成部会編，篠原出版新 社)が各 7 校であった。

問 6 「教育内容で特に重点を置いて講義している内 容について」は, HIS (hospital information system), RIS (radiological information system), PACS どの医療 情報システムに関する内容が 10 校と最も多く, 個人 情報保護法については 3 校, 医療情報システムの安全 管理に関する内容については 0 校であった(Fig. 5).

問 7「医療情報技師等の情報関連の資格に対する学 生への受検の勧めについて」は, “学生に受検を勧め ている”と回答した養成校は 8 校と全体の 4 割弱であっ た。そのうち学生の受検動向を把握している養成校 は 2 校程度であった。

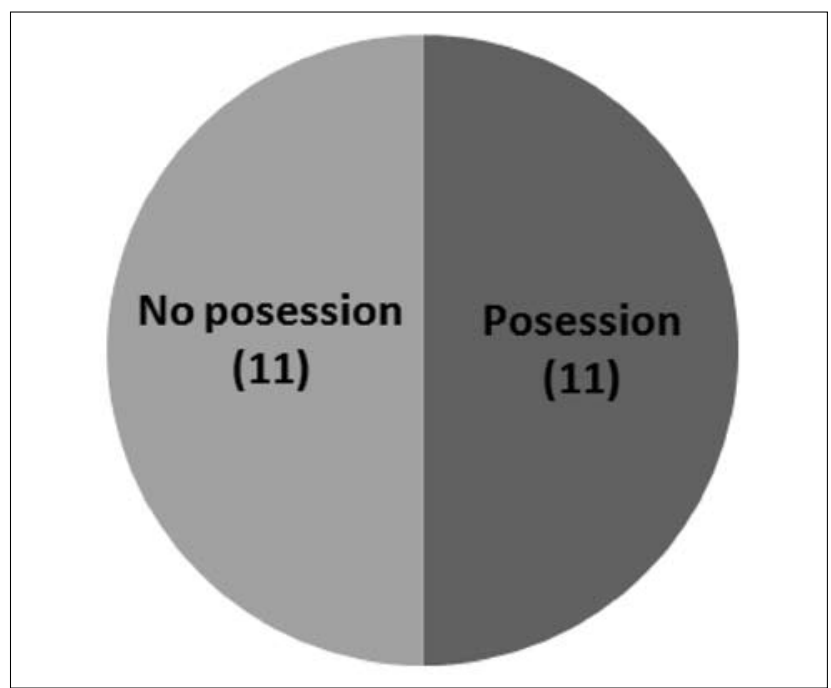

Fig. 2 Percentage and number of schools with laboratories or courses on medical information.

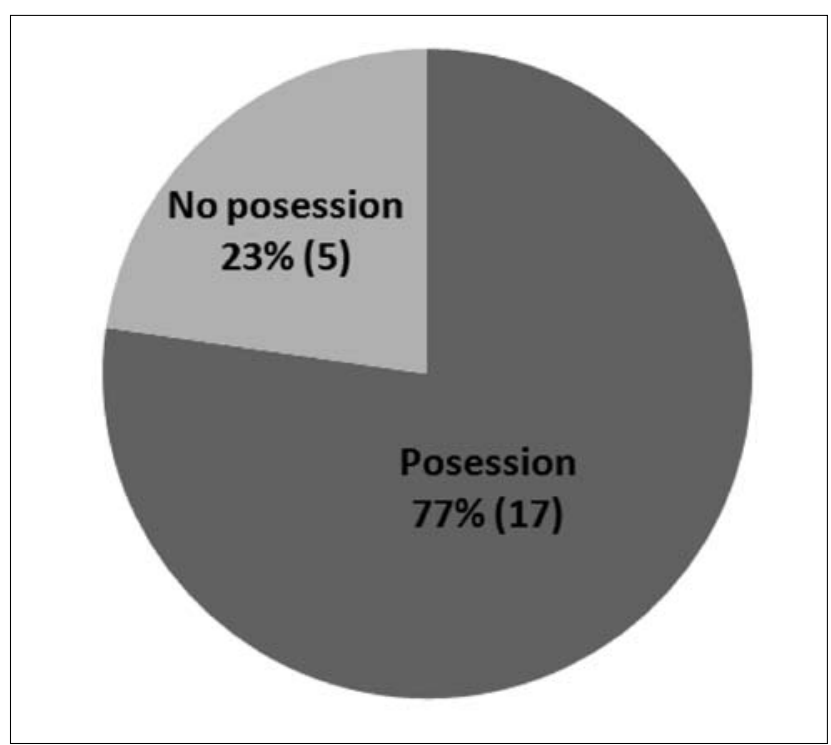

Fig. 4 Percentage and number of schools with medical information education facility.

2-3＼cjkstart医療情報教育の現状の問題点と今後の医療 情報教育について

問 8 「医療情報教育の現状の問題点について(複数 回答)」は, “学生の意欲”と回答した養成校が 16 校と 最も多く，次いで“スタッフの不足”, “時間数の不 足”掠よび“その他”が各 14 校であった(Fig. 6)。“そ の他”の内容については，(1)教えるべき範囲・レベルが 不明確である，(2)適切な教科書や教育指針がない, (3)範囲が広すぎる/教育の体系化がされていない, (4)教育内容が複雑である, (5)医療情報担当部署との 関係が不明瞭である，6学生間に能力差がある，な 


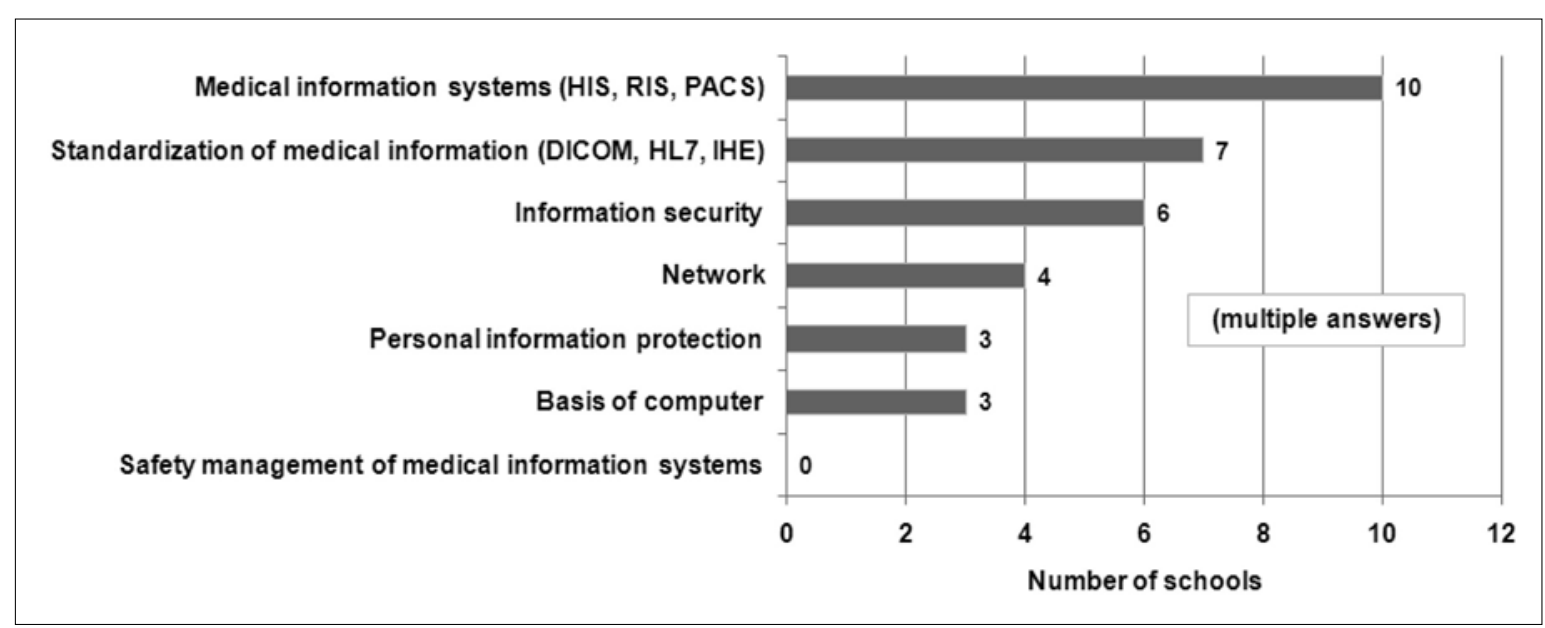

Fig. 5 Priority contents in medical information education.

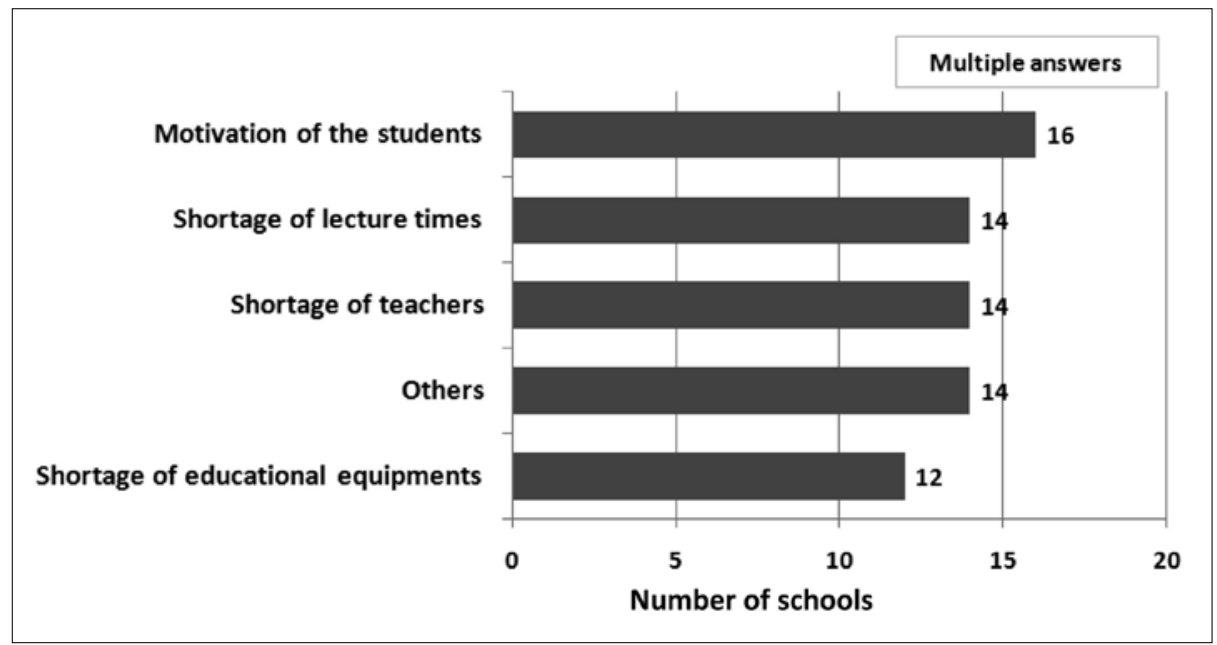

Fig. 6 Problems in medical information education.

どであった。

問 9「今後の医療情報教育に必要なものについて」 は，以下のような回答を得た。

・医療情報システム，セキュリティ等の運用・構築に 関してリーダーシップがとれる人材育成のための教育 が必要である。

・診療放射線技師が最低限必要な知識を明らかにし， 養成機関での教育システムを効率よくすべきである。

・医療現場の情報化が進んできているため，実際に 医療情報システムを使った医療情報教育が必要であ る.

・医療情報学を独立した科目として構築する必要が ある。

・ネットワーク技術や情報システムの構築に用いられ る技術，セキュリテイやプライバシー保護について もより深い教育が必要である。電子保存を実施す るためにどのような技術や運用管理が必要となるか
という視点で，講義すべき内容を体系化することも 必要と考える。

・医療情報システムの使命は，医療の質の向上，医 療の安全確保，医療の効率化にあると考えるため, このことを実現するには情報の共有化や統合化が 重要となってくる.

・これからの診療放射線技師教育のなかに医療情報 に関する教育をどの範囲まで組み入れていくかは 検討の余地がある。診療放射線技師教育において 医療情報という応用分野を扱うには，その基盤に 医学・医療と情報処理技術の基礎を理解しておくこ とが必須である。実際の現場での場面を教育内容 に反映させながら，現場で要求される知識や技術 の基礎を補完していくことが必要である，また，社会 のニーズに合わせた教育内容の構築が必要である.

・医療情報教育には卒前教育だけでなく卒後教育の 充実も必要である。 
・最低限，エンドユーザとして医療情報倫理や個人 情報保護法, 情報セキュリティの概念など基本的 な医療情報を理解させる必要がある.

・今後の医療情報教育の重要性はさらに増していく と考えられるが, 将来の診療放射線技師像や社会 的な役割とも深く関わるため現時点では回答は困難 である。

\section{2-4 その他}

問 10 「自由記載」については，以下のような回答を 得た。代表的なものをおおむね原文のまま示す。

・医療情報というとかなり広い範囲にわたる学問で, しかも十分に体系化されているともいえず，また国 によっても事情が異なる.

・診療放射線技師教育に必要な医療情報の分野のス キルの範囲とレベルをもう少し具体化することを要 求してはどうか.

- 今回の調査結果を受けて医療現場の現状や要求も 踏まえ, 出題基準の見直しも行っていくべきかと思う.

・放射線部門の仕事としてネットワークやシステム管 理を考える必要があるか？ 現実的には臨床現場 で求められており，放射線部門の仕事の一部になり つつある. しかし，本当の管理あるいはシステムの 構築を放射線部門のなかで担当できる技師は希で はないか?

・医療情報(学)は，十分に体系づけられた領域では なく専門家レベルの教育のためにはハードウェアか ら運用管理論までと膨大な知識が必要である。

・医療技術職として必要十分な知識をまとめた教科 書等がもっと必要だろう。

・医療情報部との仕事区分を明確にし, 必要な範囲 に関して重点を絞るべきだと思う。

・診療放射線技師試験対策としてどこまで踏み込ん で教育すれば良いか判断に困っている.

\section{3. 考 察}

医療情報教育の教育環境については，大学の約 7 割が医療情報に関わる教育または研究を行う講座ま たは研究室が設置されていたにもかかわらず，医療 情報学の専任教員を配置している養成校は全体の 4 割弱であった。このおもな要因は画像工学分野を専 門とする教員が医療情報学分野の教育を兼任してい ることによるものである。医療情報教育のための設備 は, 全体の 8 割弱の養成校で数十台のパーソナルコ ンピュータ $(\mathrm{PC})$ が設置されており, 基礎的な情報教 育体制は整備されていると推察される。しかし, 医療 情報教育という専門教育に関わる設備については, 教育用 PACS や HIS など教育用医療情報システムを
導入している養成校はそのうちの約 5 割を占めていた。 このような現状を踏まえると，養成校間で医療情報の 教育環境に差が生じていると考えられる，各養成校 において教育用医療情報システムを導入するには金銭 的な問題が生じるため, 今後養成校での医療情報教 育の充実のために医療情報学に関連する学会等が中 心となって既存の PC を利用した医療情報教育用ソフ トウェアの開発・提供も検討していく必要があろう。

医療情報に関わる講義において特に重点を置いて 講義している内容は, HIS, RIS, PACSなどの医療 情報システムに関する内容が大部分を占め, 医療情 報の保護やプライバシーなど医療情報の安全管理に 関する内容については少数であった。このことは，診 療放射線技師国家試験出題基準 ${ }^{8)}$ や近年の国家試験 の出題傾向から考えると当然の結果と考えられる. 2003 年に取りまとめられた平成 16 年版診療放射線 技師試験出題基準は，2003 年に公布された個人情報 保護法, 厚生労働省より公表された「医療・介護関係 事業者における個人情報の適切な取扱いのためのガ イドライン (初版 2004 年) 」14) と「医療情報システムの 安全管理に関するガイドライン(初版 2005 年) 」15)に 対応していない. 他方, 2009 年 5 月に改定された平 成 23 年版臨床検査技師国家試験出題基準では, X 章・医用工学概論において大項目「医療情報システム」 のなかに中項目として「B 医療情報の保護とプライ バシー」が設定されており ${ }^{16)}$, 近い将来診療放射線技 師国家試験出題基準の見直しも必要であろう.

医療情報教育の現状の問題点では, 多くの養成校 で“学生の意欲が低い”との回答を得た。これは，国 家試験を意識した教育内容によること，学生にとって 発展性がなく興味を持ちにくいこと, 医療情報分野 が診療放射線技師の仕事に該当するかなど教育側と 学生側にそれぞれの要因が含まれると考えられる. 今後, 教員側と学生側にアンケート調査を実施し教育 上の問題点を検証する必要がある。また，適切な教 科書がない，範囲が広すぎる，教育の体系化がされ ていないなど，つまり “教えるべき範囲・レベルが不 明確”という意見が多かった。これは, 問 2 , 問 9 お よび問 10 の回答より, 医療情報の基礎となる情報処 理技術を理解するためには，ネットワーク技術，デー タベース技術, 情報セキュリティ, システム開発・管 理などの広範囲にわたる知識が必要であり, それら を現在の講義・演習時間内で実施するには困難である などの理由が推察される。今後“教えるべき範囲・レ ベル”に関する具体的な調査を実施し, 教育内容につ いて検証する必要がある.

今後，診療放射線技師教育において医療情報教育 を充実させるためには，医療情報学を現在の医用画 
像情報学から独立させて基礎となる情報工学分野を 設定するなど教育ビジョンを明確に示す必要がある. また，各養成校では，医療情報分野でリーダーシッ プがとれる人材育成のために，医療現場に即した教 育体制を構築し, 卒前・卒後教育に対応させることも 必要になろう。

\section{4. 結 語}

本調査研究では，診療放射線技師養成機関におけ る医療情報教育の実態調査を実施した。その結果， 専任教員や教育設備の面から養成校間で医療情報の 教育環境に差があることが明らかとなった。また，教
育現場では医療情報教育に苦慮しており，医療情報 教育のための教育指針や教科書が必要であることも 明らかとなった。よって，本調査結果は，診療放射 線技師教育における医療情報教育のビジョンを示す 必要があることを示唆するものである.

\section{謝 辞}

本調査研究にご協力いただいた診療放射線技師養 成機関の先生方に深謝いたします。

本調査研究は，（社) 日本放射線技術学会・平成 20 年度学術調查研究班「医療情報教育に関する調査研 究」の研究助成によって行われた。

\section{参考文献}

1）厚生労働省. 医療・健康・介護・福祉分野の情報化グランド デザイン. 2007 年 3 月. http://www.mhlw.go.jp/houdou/ 2007/03/h0327-3.html(2010 年 2 月 25 日アクセス).

2) IT 戦略本部. i-Japan 戦略 2015 一国民主役の「デジタル安 心・活力社会」の実現を目指して一. 2009 年 7 月. http:// www.kantei.go.jp/jp/singi/it2/kettei/090706honbun.pdf (2010 年 2 月 25 日アクセス).

3）中央教育審議会. 学士課程教育の構築に向けて(答申) 2008 年 12 月. http://www.mext.go.jp/component/b_menu/ shingi/toushin/_icsFiles/afieldfile/2008/12/26/1217067_001.pdf (2010 年 2 月 25 日アクセス).

4) 文部科学省・厚生労働省. 診療放射線技師学校養成所指 定規則の一部を改正する省令. 2001.

5) 厚生労働省医政局. 診療放射線技師養成所の指導要領に ついて. 2003.

6）松本満臣. 診療放射線技師教育の流れ一第 2 報一大綱化 カリキュラムと教育目標— . 日放技学誌 2001; 57(2): 185-189.

7）松本満臣. 診療放射線技師教育の流れ一第 3 報一大綱化 カリキュラムの要点と考え方一. 日放技学誌 2001; 57(3): 258-263.

8) 医事試験制度研究会. 平成 16 年版診療放射線技師試験 出題基準。東京：選択エージェンシー, 2003.

9) 小笠原克彦, 松村 宰, 櫻井恒太郎. 医療情報学受講前の 情報リテラシーの学科間相違に関する考察一医学科・看護 学科·診療放射線技術学科学生を対象とした 7 年間の継続
調査結果一. 医療情報学 2005; 25(1): 7-13.

10) 浅利 覚, 松谷秀哉, 柏倉幾郎. 放射線技術科学専攻に おける医用情報関連教育(第 1 報)一専門科目「コンピュー夕 概論」授業開始前におけるコンピュータリテラシーの実態 調査一. 弘前大保健紀 2005; 4(4): 75-81.

11）浅利 覚, 松谷秀哉, 柏倉幾郎. 放射線技術科学専攻に おける医用情報関連教育(第 2 報)一専門科目「コンピュータ 概論」授業終了後のアンケートによる授業評価一，弘前大 保健紀 2006; 5(5): 173-177.

12）大場久照, 松谷秀哉, 柏倉幾郎. 放射線技術科学専攻学 部生の情報リテラシーに関する調査研究. 日放技学誌 2009; 65(1): 35-40.

13）開原成允, 稲田 紘. 医療情報学の確立. 医療情報学. 情報処理学会, 東京, 1980: 169-173.

14）厚生労働省。医療・介護関係事業者における個人情報の 適切な取扱いのためのガイドライン。 2006 年 4 月改正. http://www.mhlw.go.jp/topics/bukyoku/seisaku/kojin/ dl/170805-11a.pdf(2010 年 2 月 25 日アクセス).

15）厚生労働省. 医療情報システムの安全管理に関するガイ ドライン第 4.1 版. 2010 年 2 月. http://www.mhlw.go.jp/ shingi/2010/02/s0202-4.html(2010 年 2 月 25 日アクセス).

16）厚生労働省. 平成 23 年版臨床検査技師国家試験出題基準 $\mathrm{X}$ 章 医用工学概論. 2009 年 5 月. http://www.mhlw.go.jp/ topics/2009/05/d1/tp0513-1o.pdf(2010 年 2 月 25 日アクセス).

Fig. 1 教育形態別の回答率と養成校数

Fig. 2 医療情報に関わる研究室を有する養成校の割合

Fig. 3 医療情報学を専門とする専任教員を配置している養成校数

Fig. 4 医療情報教育に関わる教育設備を有する養成校の割合

Fig. 5 医療情報教育での重点内容

Fig. 6 医療情報教育に関する現状の問題点 